\title{
Recorregut de recerca geològica i mineralògica per les comarques del Baix Camp i del Priorat: des de les Borges del Camp a l'Alforja i a la Mussara
}

Josep Maria Mata-Perelló

Joaquim Sanz Balagué

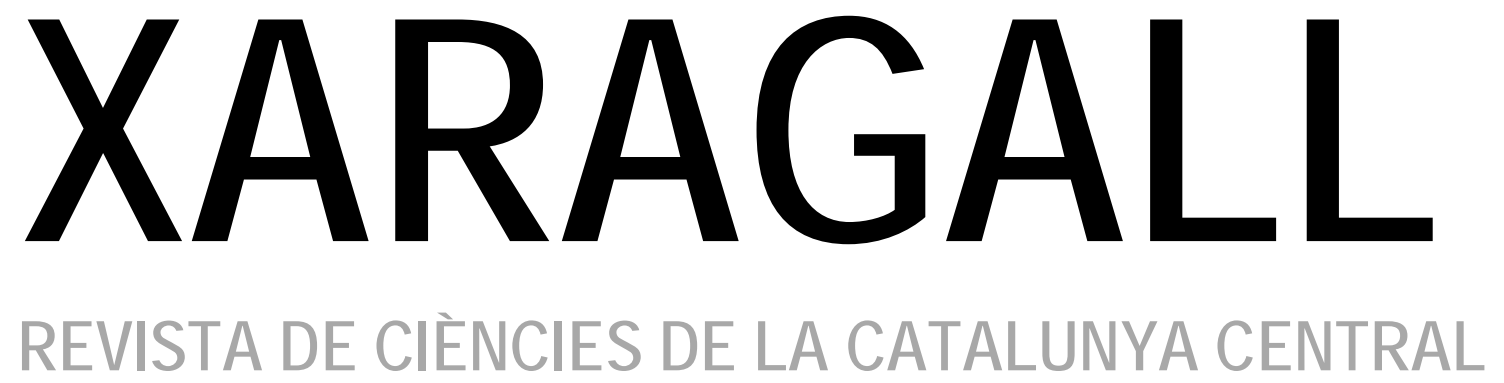

n. 4

ABRIL 2015 


\title{
RECORREGUT DE RECERCA GEOLÒGICA I MINERALÒGICA PER LES COMARQUES DEL BAIX CAMP I DEL PRIORAT: DES DE LES BORGES DEL CAMP A L'ALFORJA I A LA MUSSARA
}

\author{
Josep Maria Mata-Perelló \\ Museu de geologia Valentí Masachs, Escola Politècnica Superior d'Enginyeria de Manresa \\ (EPSEM), Universitat Politècnica de Catalunya · BarcelonaTech (UPC), 08272 Manresa, Spain
}

\section{Joaquim Sanz Balagué}

Departament d'Enginyeria Minera i Recursos Naturals (EMRN), Escola Politècnica Superior d'Enginyeria de Manresa (EPSEM), Universitat Politècnica de Catalunya . BarcelonaTech (UPC), 08272 Manresa, Spain

Paraules clau: Sistema Mediterrani, Patrimoni miner

\begin{abstract}
Resum
Itinerari realitzat el 24 de maig de 2014. En aquesta ocasió, el recorregut de l'itinerari discorrerà, en la seva major part pel sistema Mediterrani (i més concretament per la seva sotsunitat més interna, la Serralada Prelitoral Catalana). Així, discorrerà pràcticament entre les Borges del Camp, I'Alforja i la Mussara, tot passant per les immediacions de Cornudella de Montsant i de I’Arbolí.
\end{abstract}

Tot i així, també cal dir que també discorrerà, però molt inicialment, per la Depressió Prelitoral Catalana (també del Sistema Mediterrani), per les immediacions de Borges del Camp. Tot i així, la totalitat del recorregut transitarà exclusivament per la Serralada Prelitoral Catalana.

Així doncs, el recorregut de l'itinerari s'iniciarà a la segona sots-unitat geològica, però s'haurà començat en realitat a la Depressió Prelitoral Catalana, per la qual discorrerà pel poble de les Borges del Camp. Després, de sobrepassar aquesta població es penetrarà a la Serralada Prelitoral Catalana, per la qual es transitarà fins a la finalització a la Mussara.

Per altra banda, la totalitat del recorregut es realitzarà quasi totalment per dintre de la comarca del Baix Camp, des la localitat de les Borges del Camp fins a l'esmentada de la Mussara. Tot i així s' haurà entrat breument a la comarca del Priorat, tot fent una fillola des del Coll d'Alforja. 


\section{Objectius fonamentals}

Els objectius fonamentals que es pretenen aconseguir en aquest itinerari, es poden concretar en els següents aspectes generals:

1. Observació de la Depressió Prelitoral catalana, per on s'iniciarà el recorregut de l'itinerari a la població de les Borges del Camp.

2. Reconeixement dels materials cenozoics (del Miocè), i dels quaternaris, que reblen la Depressió Prelitoral Catalana, els quals tallarem entre els indrets inicials abans esmentats de l'itinerari.

3. Estudi i observació de la Serralada Prelitoral Catalana (integrada dintre del Sistema Mediterrani), per la qual discorrerà el recorregut de l'itinerari en quasi tot el seu recorregut, entre les Borges del Camp i la Mussara.

4. Reconeixement dels materials paleozoics (del Carbonífer), i dels mesozoics (del Triàsic). que constitueixen la Serralada Prelitoral Catalana, els quals tallarem entre els indrets abans esmentats. Així, els carbonífers, els tindrem presents al llarg de gairebé tot el recorregut; mentre que els triàsics els tallarem al entre el Coll d'Alforja i la localitat de la Mussara.

5. Visió de diferents mineralitzacions situades al llarg del recorregut de l'itinerari. Com és el cas de les següents:

5A) de les mineralitzacions de ferro associades a skarn, que trobarem prop de les Borges del Camp (Baix Camp), entre els materials carbonífers de la Serralada Prelitoral Catalana. $5 B$ ) de les mineralitzacions supergèniques d'alteració de minerals de coure, que trobarem a l'Alforja (Baix Camp), sobre l'antiga mina de coure. Les veurem entre afloraments dels materials paleozoics.

5C) de les mineralitzacions filonianes cupríferes, que trobarem al Barranc Fondo, prop de Cornudella del Montsant (Priorat) entre els materials paleozoics

6. Observació de les diferents explotacions mineres que anirem trobant al llarg del recorregut; així, a més a més de les anteriorment esmentades, també trobarem:

6A) les antigues explotacions de materials granítics situades entre les Borges del Camp i I’Alforja.

6B) les actuals explotacions de quarsites situades entre I'Alforja i el coll del mateix nom, a la vora de la carretera.

6C) les actuals explotacions de calcàries i dolomies triàsiques situades per sobre del Coll d'Alforja.

6D) les antigues explotacions de guixos triàsics situades entre el coll acabat d'esmentar i la Mussara.

7. Observació, si s'escau, de les tasques de restauració dutes a terme a les explotacions anteriors.

8. Observació de diferents indrets del Patrimoni Geològic i Miner, situats al llarg del recorregut. Entre aquests elements, cal parlar dels impressionats relleus de la Mussara, entre molts altres indrets del recorregut de l'itinerari. 


\section{Antecedents}

Pel que fa al recorregut del present itinerari, existeixen diversos antecedents nostres, de tipus bibliogràfic referent a diferents indrets del recorregut de l'itinerari. Es tracta de MATAPERELLÓ i COLLDEFORNS (1994); així com els de MATA-PERELLÓ (1995, 1996, 1998, 2000, 2004, 2005, 2008a, 2008b, 2011a, 2011b i 2012).

Pel que fa a la descripció de les mineralitzacions d'aquesta comarca, cal parlar dels treballs de MATA-PERELLÓ (1991), relatiu a les mineralitzacions catalanes en general; i també dels de MELGAREJO (1992), centrat en els materials i les mineralitzacions del paleozoic, de les comarques del Baix Camp, de la Conca de Barberà i del Priorat

Per altra banda, i pel que fa a les característiques dels materials geològics que anirem tallant, ens referirem als treballs de COLOMBO (1986 i 1989). I pel que fa a l'estructura geològica farem esment de dos treballs; de: GUIMERÀ et altri (1982) i de RIBA et altri (1976).

Tots aquests treballs referenciats, i d'altres, figuren esmentats per ordre alfabètic a l'apartat dedicat a la BIBLIOGRAFIA.

\section{Recorregut de l'itinerari}

Tot i que el recorregut s'iniciarà a la població de les Borges del Camp, caldrà sortir per la carretera C - 242, per tal de fer una aturada prop del poble. Tot seguit, el recorregut continuarà per la carretera C-242, cap al poble de I'Alforja, per on es realitzaran diverses aturades dintre del seu terme.

Després, el recorregut continuarà cap al Coll d'Alforja, on es realitzarà una nova aturada prop del mateix coll. Des de l'esmentat Coll d'Alforja el recorregut de l'itinerari es dirigirà cap a llevant, tot passant per les immediacions d'Arbolí, dels Castillejos, de la Mussara, per on finalitzarà. En aquest recorregut es faran diverses aturades.

\section{Advertiments previs}

Com en altres recorreguts de RECERCA GEOLÒGICA I MINERALÒGICA... si es disposa del temps suficient, poden efectuar-se passant per totes les parades i filloles. En cas contrari, recomanem reestructurar el recorregut, prescindint de les anomenades PARADES CONDICIONALS, i d'altres si s'escau.

També recomanem de cercar la informació més adient, sobre els trams a recórrer mitjançant camins de terra, o de pista.

Per altra banda, recomanem tenir una cura extrema de la NATURA, evitant qualsevol forma d'agressió sobre ella, o de fer-n'hi un mal ús del que en ofereix la nostra mare Terra. 


\section{Descripció de l'itinerari}

Com en altres itineraris, aquest s'estructurarà en base a una sèrie de PARADES 0 d'ESTACIONS que anirem veient a continuació. En cada una d'aquests aturades es farà un breu comentari., de tipus geològic o mineralògic, relatiu a l'indret, segons s'ensalgui.

Per d'altra banda, darrera del nom de l'indret situarem (entre parèntesi) el número del full del Mapa Topogràfic, a escala 1:50.000, on es troba situat. En aquest itinerari, utilitzarem els següents fulls: $\mathbf{4 4 5}$ (o de Cornudella), $\mathbf{4 7 1}$ (dit de Mora d’Ebre) i $\mathbf{4 7 2}$ (dit de Reus).

A continuació, començarem la descripció de les diferents aturades que formen part del present recorregut.

\subsection{Parada 1. MINES DE LA MARE DE DEU DE LA RIERA, (terme de les Borges del Camp, comarca del Baix Camp). (Full 445).}

El recorregut l'iniciarem al poble de les Borges del Camp. Després, Sortint del poble per la carretera C - 242, després d'un recorregut per ella d'uns $500 \mathrm{~m}$ (des del poble), es troba un camí per l'esquerra, el qual es dirigeix a la Riera de l'Alforja, i que després de remuntar-la durant uns $100 \mathrm{~m}$., la travessa. A continuació, en poc més de $200 \mathrm{~m}$, s'arriba a les antigues Mines de la Mare de Deu de la Riera, de les Borges del Camp. En aquest lloc, i després d'un recorregut proper a 1'5 $\mathrm{Km}$ des de la sortida.

En aquest recorregut, s'haurà anat circulant per entre els materials quaternaris que cobreixen als miocènics. Uns i altres reblen la Depressió Prelitoral Catalana, per on es troba situada la població de les Borges del Camp.

Després, prop de l'indret de la parada, s'ha passat sempre per la Serralada Prelitoral Catalana, on ara ens trobem. Així, s'han anat tallant materials del Carbonífer, constituïts per nivells d'esquits.

Així, en aquest indret es troba un aflorament de nivells esquistosos (calcosquistos) del Carbonífer. Aquest materials es troben en contacte amb uns afloraments granítics, els quals es fan palesos a la Riera d'Alforja, però no a l'indret de l'aturada.

En aquest lloc es troba una interessant mineralització associada a skarn, desenvolupada al contacte entre els materials abans esmentats. Entre els minerals presents, cal fer esment de la presència de MAGNETITA, la qual es va explotar a diferents èpoques.

També es troben abundants minerals de coure, especialment amb CALCOPIRITA I MALAQUITA (formada a partir de l'alteració de I'anterior). I, tanmateix, es troben altres minerals com I'EPIDOTA.

Pel que fa a la mina soterrània, cal dir que a l'actualitat es troba mig enrunada. (fotografia 1). Per altra banda, també cal dir que existeixen diverses zones d'explotació dels minerals de ferro. 


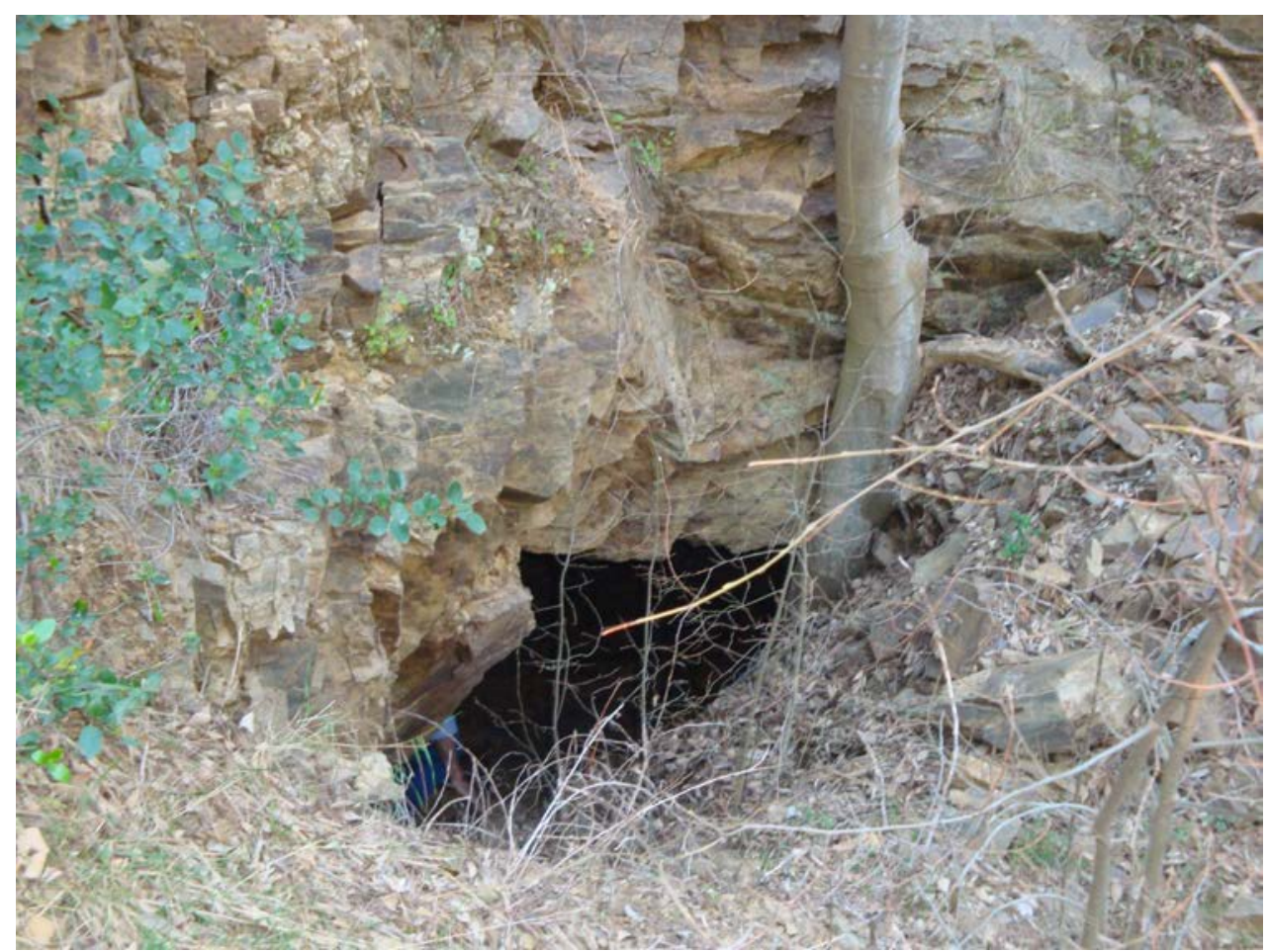

Fotografia 1. Una de les antigues "bocamines" de les Borges del Camp

\subsection{Parada 2 - CONDICIONAL. ANTIGUES EXPLOTACIONS DE ROQUES GRANÍTIQUES DE LES BORGES DEL CAMP, (terme municipal de les Borges del Camp, comarca del Baix Camp). (Full 445).}

Després de fer l'aturada anterior, cal retornar cap a la carretera comarcal C-242, tot anant ara cap a I'Alforja. Quasi en arribar a la gasolinera situada entre ambdues poblacions, caldrà fer la present aturada, després de recórrer uns $3 \mathrm{Km}$ des de la parada anterior.

En aquest recorregut, haurem circulat per entre afloraments de terrenys paleozoics de la Serralada Prelitoral Catalana. Així, haurem trobat afloraments de roques granítiques (generalment de granodiorites) molt alterades.

Aquí en aquest lloc, va haver-hi una antiga explotació dels materials granítics (és a dir: de les esmentades granodiorites). Aquesta explotació es dedicava a extreure blocs, per tal de fer llambordes a continuació.

Entre els afloraments de les roques granítiques, es poden observar fenòmens de saulinitització, per transformació dels feldspats en caolí, com a conseqüència dels processos geològics externs.

Amb aquesta alteració (caolinització), la roca granítica es desmorona, donant lloc a una roca arenosa denominada sauló, la qual sovint es explotada, per a ésser emprada com a material de construcció, com a àrid. 


\subsection{Parada 3. ANTIGUES MINES DE COURE DE L'ALFORJA I EXPLOTACIÓ ACTUAL DE "CUARCITAS DEL MEDITERRANEO", (terme municipal de I'Alforja, comarca del Baix Camp), (Full 445).}

Després de fer la parada anterior, cal continuar cap a l'Alforja. Després, en sortir del poble, continuant sempre per la carretera comarcal C-242, en el seu sentit cap al Coll d'Alforja i cap a Cornudella del Montsant, ens caldrà arribar a les immediacions del seu Km 57'4 (a uns 2 Km del poble).

En aquest indret hi ha unes explotacions actuals de pòrfirs i de quarsites. Així, per tal d'arribar fins aquest indret, ens haurà calgut recórrer uns $5^{\prime} 5 \mathrm{Km}$, des de la parada realitzada anteriorment.

En tot el recorregut, es van tallant els materials granítics del Clap de l'Alforja, i també els terrenys carbonífers, constituïts per esquistos i quarsites, sovint tallats per pòrfirs granítics. A la pedrera abans esmentada (del Km 57'4), de l'empresa Cuarcitas del Mediterráneo S.A., s'aprofiten uns i altres materials, els quals s'utilitzen per a l'obtenció d'àrids artificials, en triturar els materials abans esmentats. Sovint, entre aquesta materials es troben cristal-litzacions de PIRITA. Per d'altra banda, cal dir que l'escombrera d'aquestes extraccions ha arribat a tapar, quasi completament, les antigues i importants Mines de Coure de I'Alforja, les quals es trobaven per sota de la carretera i de les actuals explotacions de la pedrera abans esmentada.

Les antigues mines de coure de I'Alforja, es troben sobre unes mineralitzacions de sulfurs en skarns (MELGAREJO, 1992). Aquestes es troben al contacte entre nivells calcosilicatats del Carbonífer i el granits de I'Alforja. El mineral més abundant és la CALCOPIRITA, la qual va ésser motiu d'explotació.

Amb ella s' hi troben altres minerals, com els següents entre d'altres: ESFALERITA, GALENA, PIRROTINA, PIRITA, GAHNITA, ACTINOLITA, DIÒPSID, EPIDOTA, GRANATS, HEDENBERGITA, QUARS i TREMOLITA. També es poden trobar minerals d'alteració com: GOETHITA, ATZURITA, CERUSSITA, MALAQUITA i SMITHSONITA.

Tot i això, els minerals de coure són els més abundants. Malgrat això, actualment es força difícil de recercar minerals, i alhora perillós, com a conseqüència de l'actual explotació inicialment esmentada, situada per sobre de la mina. Tot i així, cal dir que encara es possible trobar una boca mig enrunada a la vora de la carretera (a l'esquerra de l'actual explotació), on es fan paleses les mineralitzacions, i sobretot les alteracions de MALAQUITA. (fotografia 2). 


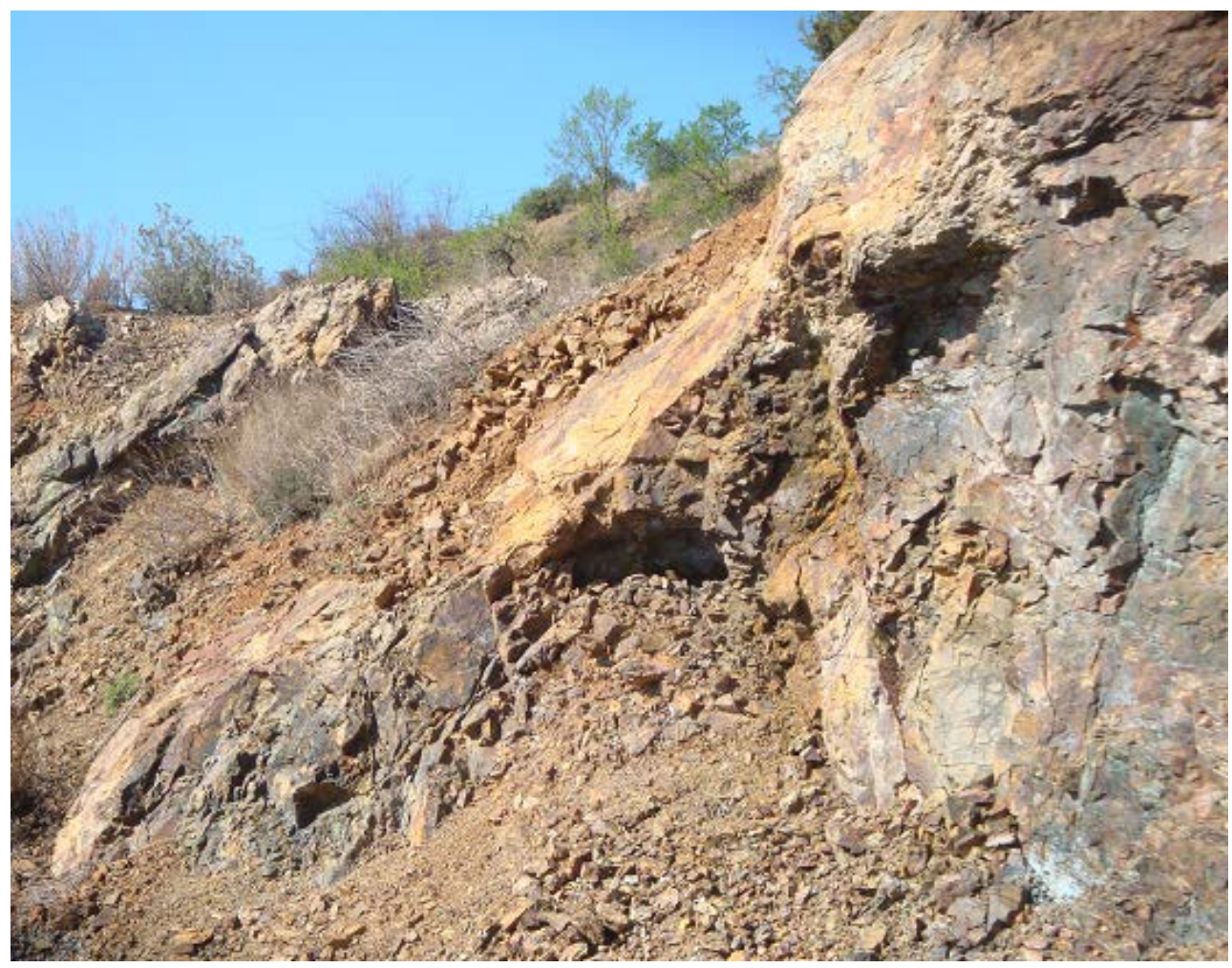

Fotografia 2. Un aspecte de les mineralitzacions supergèniques dels minerals de coure. L'alforja

Per altra banda, des d'aquest indret, i mirant cap al Nord i cal a llevant, es poden veure uns interessants afloraments dels nivells de gresos rogencs del Buntsandstein (del Triàsic Inferior). Aquests terrenys mesozoics es troben enlairats, i es situen per sobre dels paleozoics abans esmentats, en una posició clarament discordant amb aquells. (fotografíes 3 i 4).

Per altra banda, des d'aquest indret, es pot veure clarament l'explotació dels materials paleozoics, en una pedrera. Dintre d'ella es poden veure les instal-lacions de tractament de les roques. (fotografía 3). Tot i així, per entrar-hi, cal demanar autorització a l'empresa minera. 


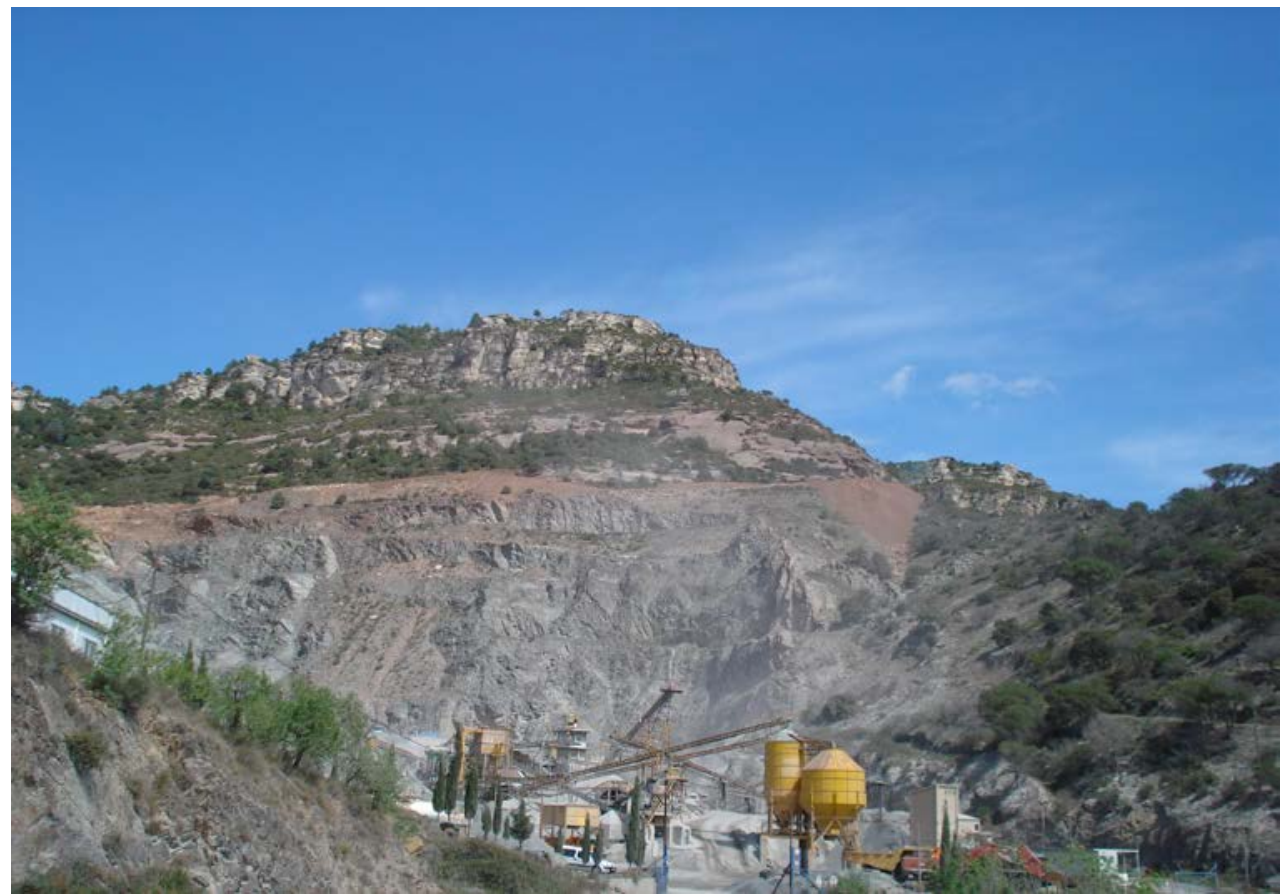

Fotografia 3. Detall de l'explotació dels materials paleozoics. Per sobre de l'explotació es fan palesos els materials triàsics del Buntsandstein i del Muschelkalk

Finalment, cal dir que entre aquests afloraments dels gresos rogencs es fan clarament paleses unes interessants estructures alveolars, ben visibles des de la carretera, a una certa distancia d'on es troben.

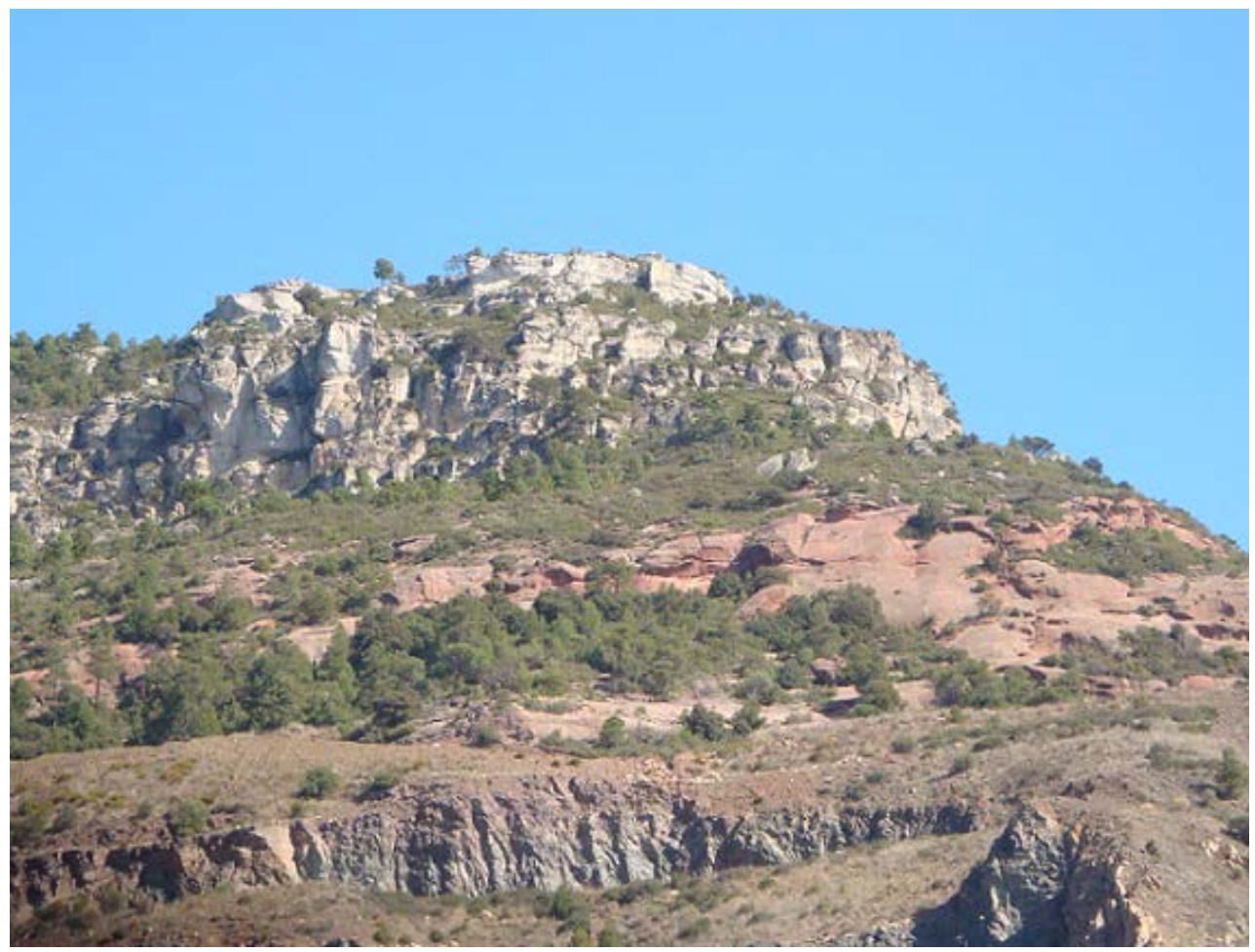

Fotografia 4. Un altre aspecte de l'explotació, del materials triàsics del Buntsandstein i del Muschelkalk 


\subsection{Parada 4. COLL D’ALFORJA: VISIÓ GEOLÒGICA GENERAL (terme municipal de I’Alforja, comarca del Baix Camp). (Full 445).}

Després de visitar les explotacions anteriors, cal retornar a la carretera C-242, i continuar en el mateix sentit, tot anant cap al NW, cap al Coll d’Alforja, i també cap a Cornudella. Així, la carretera va ascendint cap el Coll d'Alforja. En arribar al coll, a uns $6 \mathrm{Km}$ de la parada anterior, cal fer la present aturada.

En aquest recorregut, hem anat trobant els materials paleozoics ja esmentats a la parada anterior. I per sobre d'ells, però cada cop més propers, hem anat veient els materials de la base del Buntsandstein, i per sobre d'ells els terrenys carbonatats del Muschelkalk. Aquests darrers ja es fan palesos a la dreta del coll, mentre que a l'esquerra segueixen trobant-se afloraments paleozoics. Tot i això, en no trobar al coll els afloraments del Buntsandstein, ens fa veure que hi ha una falla (la qual ha motivat l'existència del coll).

Per altra banda, des d'aquest indret, i mirant cap al Sud, es pot gaudir d'una bona zona d'observació de la Serralada Prelitoral Catalana, i del seu contacte amb la Depressió Prelitoral Catalana, la qual s'estén pel Baix Camp, i més enllà per l'Alt Camp i pel Tarragonès, tot constituint l'anomenada Depressió del Camp.

\subsection{Parada 5. EXPLOTACIÓ DE CALCÀRIES DEL COLL D’ALFORJA, (terme municipal d'Arbolí, comarca del Baix Camp). (Full 445).}

Des del Coll d'Alforja, cal continuar per la carretera local que es dirigeix cap a l'Arbolí, la qual cal recórrer molt breument, fins arribar a una explotació actual, situada a uns $100 \mathrm{~m}$ de la cruïlla, i des de la parada anterior.

En aquest breu recorregut, hem anat trobant afloraments dels materials carbonatats del Muschelkalk Inferior, els quals es situen per sobre dels terrenys rogencs del Buntsandstein, els quals queden pinçats al coll com a conseqüència de la falla anteriorment esmentada.

A l'indret de l'aturada hi ha una important explotació dedicada a extreure uns nivells carbonatats triàsics anteriorment esmentats, els quals pertanyen al Muschelkalk Inferior. Aquests nivells es troben constituïts per calcàries i per dolomies. Un cop extrets aquests materials són utilitzats com a matèria prima per l'obtenció d’àrids per a la construcció. (fotografia 5). 


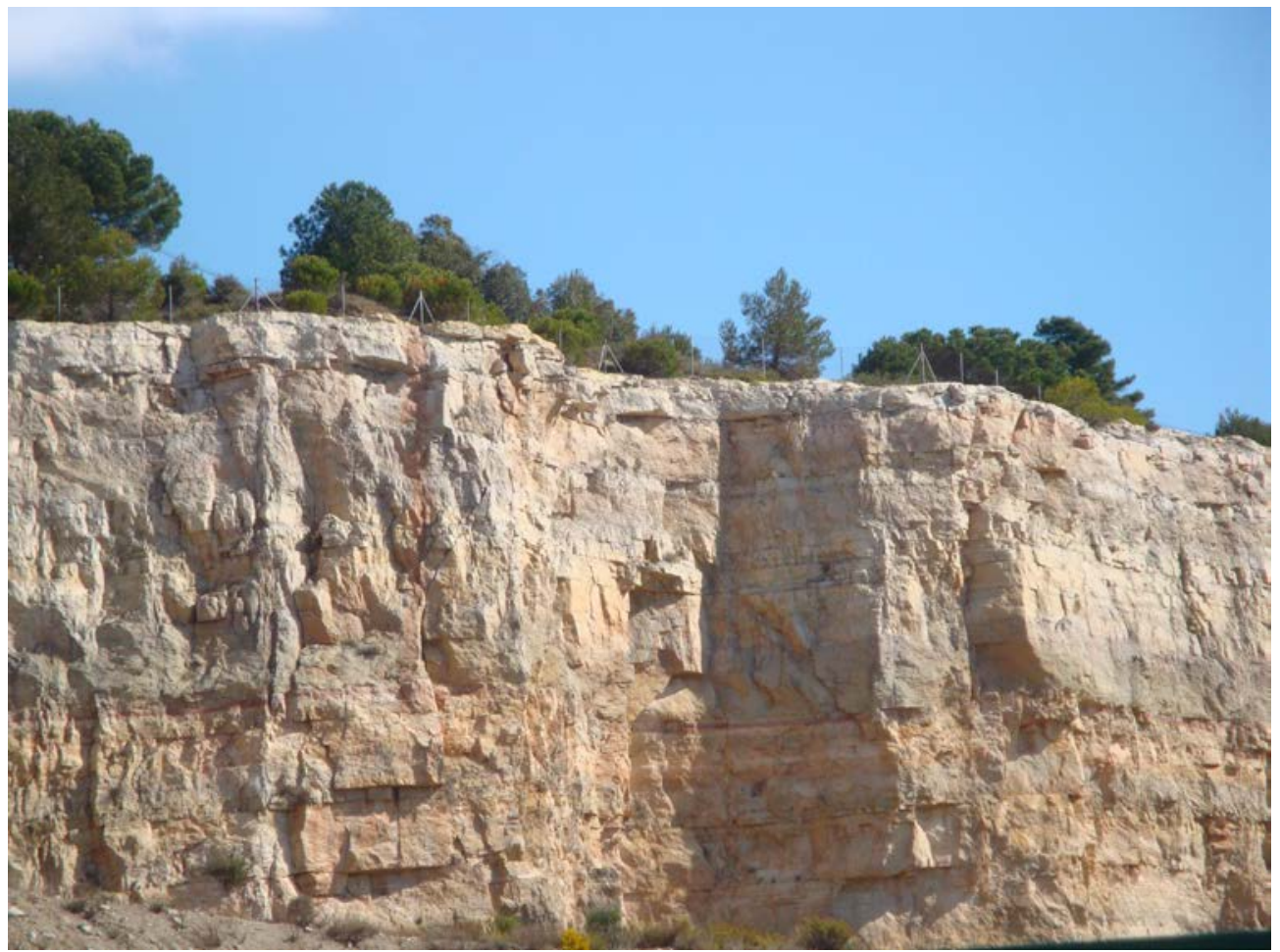

Fotografia 5. Explotació de calcàries del Muschelkalk Inferior (Coll d’ Alforja)

\subsection{Parada 6. MINES DE COURE DEL BARRANC FONDO, (terme municipal de Cornudella del Montsant, comarca del Priorat). (Full 445).}

Des de la parada anterior, cal tornar lleugerament cap enrere, al Coll d'Alforja. I, tot seguit cal continuar per la carretera C-242, per tal d'anar cap al NW, cap a Cornudella del Montsant. Després, cap a les immediacions del Km 51’1, es troba un camí per l'esquerra de la carretera, que cal agafar. Es tracta d'un camí no gaire bo, i que possiblement és millor fer-lo a peu. Aquest camí ascendent, en una mica més de $1 \mathrm{Km}$. arriba a les mines de coure del Barranc Fondo. En aquest indret cal fer la present aturada, després d'un recorregut proper als $6 \mathrm{Km}$, des de la parada anterior.

En arribar al Coll d'Alforja, hem tornat a tallar uns materials paleozoics, els quals pertanyen al Carbonífer. I, precisament l'indret de la parada es troba situat sobre aquests mateixos materials.

L'indret de l'aturada, constitueix una interessant zona minera, la qual consta de diferents boques, per les quals es pot entrar, però sempre amb les degudes precaucions, doncs hi ha pous dintre de les galeries, i despreniments, la qual cosa les fa perilloses. Aquestes mines es troben ubicades sobre unes mineralitzacions filonianes, encaixades entre els materials del Carbonífer, constituïts per nivells d'esquistos, travessats per pòrfirs. Molt possiblement es tracta de mineralitzacions associades a fractures del sòcol. 
Entre els minerals que es troben a les escombreres, cal fer esment dels següents: CALCOPIRITA (relativament abundant), PIRITA, i QUARS. I entre els minerals d'alteració, dels següents; GOETHITA, ATZURITA, MALAQUITA (molt abundant en totes les mines, fins a tenyir de color verd les fustes de les entibacions) i CRISOCOL.LA. Igualment és també molt abundant la CALCANTINA; així com la CALCITA i el QUARS, entre molts altres indicis minerals. (fotografies 6 i 7 )..

En més o menys quantitat, tots aquests minerals són fàcilment trobables a les escombreres, i a I'interior de les mines. Finalment, també cal dir que es troben indicis de minerals d'estany (possiblement d'ESTANNINA), la qual cosa no hem pogut investigar adequadament.

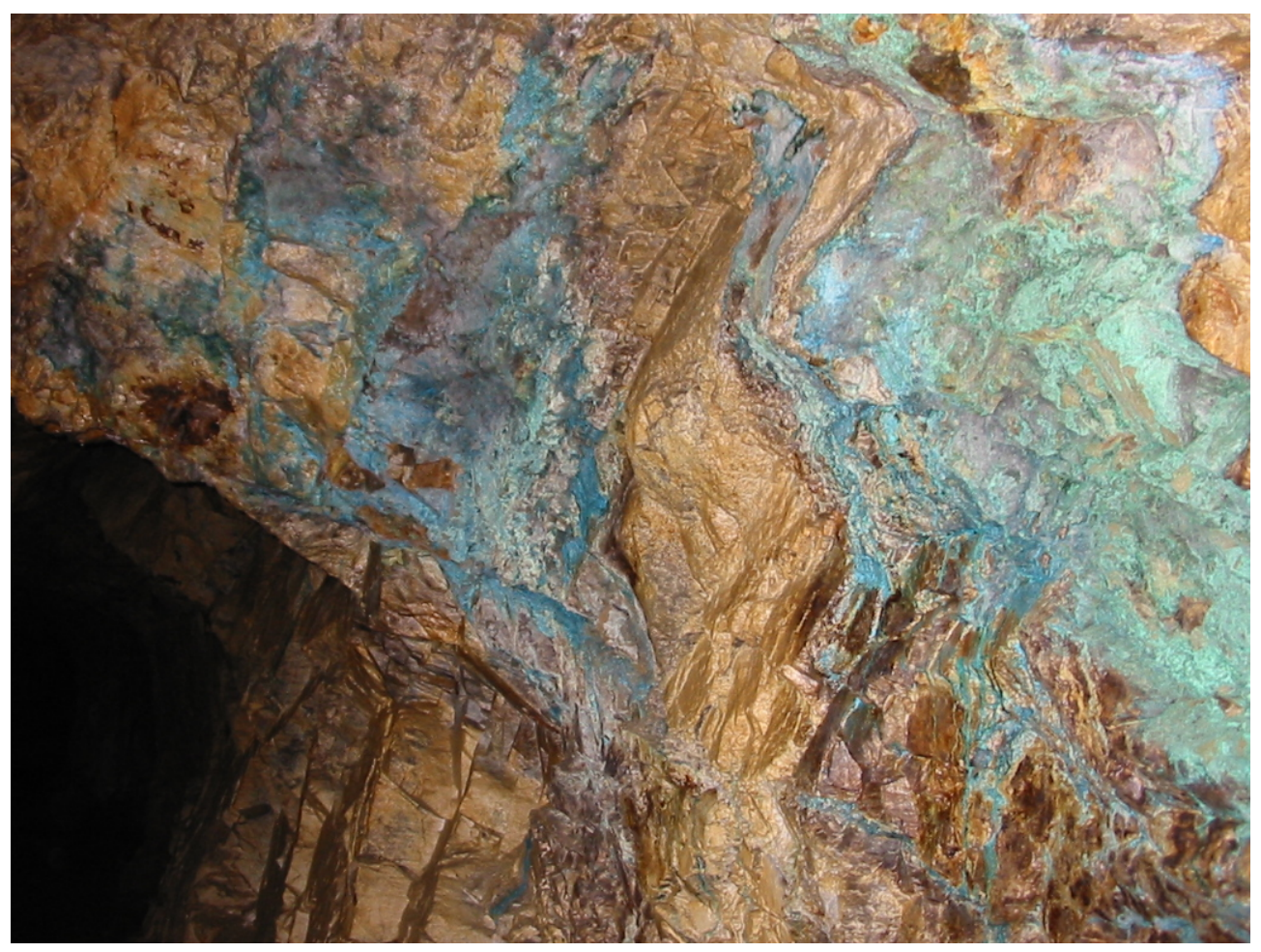

Fotografia 6. Detall de les mineralitzacions de Calcantina i de Malaquita 


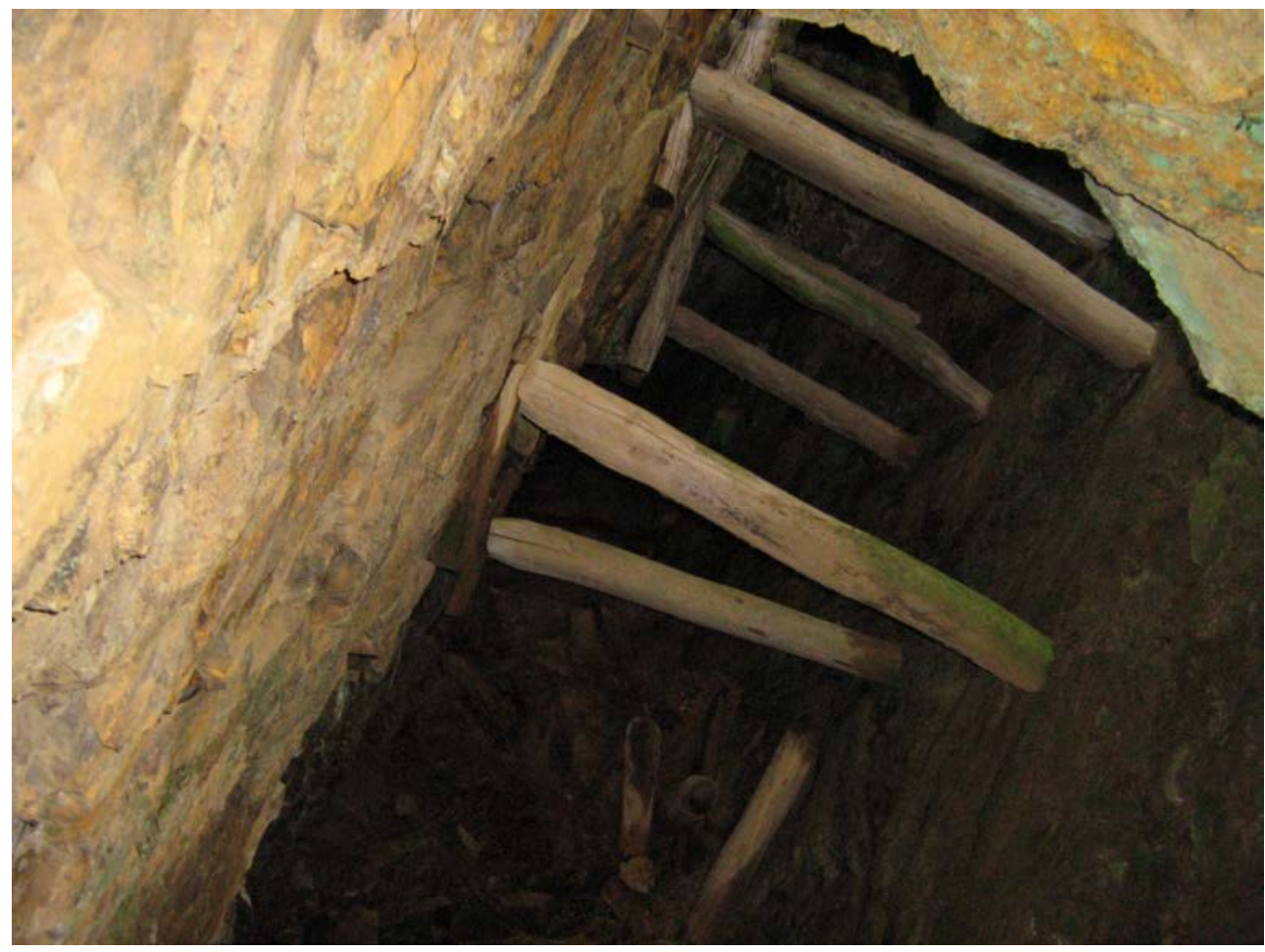

Fotografia 7. Detall de les entibacions, dintre la galeria superior de la mina

Finalment, cal dir que aquesta rodalia, forma part d'una zona minera més extensa, però en bona part perduda; cal tenir en conte, de que ja es possible que existeixin explotacions des del Neolític, d'acord amb les recerques fetes recentment, de caire arqueològic - metal-lúrgic - miner (segons comunicació verbal i manuscrita de MARTIN-ROVIRA-GALLART i MATA, 1998).

\subsection{Parada 7 - CONDICIONAL. GUIXERA D’ARBOLÍ, (terme municipal de l’Arbolí, comarca del Baix Camp). (Full 445).}

Després de fer l'aturada anterior, cal retornar de nou cap el Coll d'Alforja, per tal de continuar per la carretera TV-7012, la qual es dirigeix cap a I'Arbolí. Més endavant, a uns $2 \mathrm{Km}$ del seu inici, es troba la carretera TV-7092, la qual condueix cap a la Febró, i cap a l'antic Campamento Militar de los Castillejos. Ens cal agafar aquesta carretera, per tal d'efectuar una parada cap al voltant del $\mathrm{Km} \mathrm{3}$, després d'haver recorregut aquesta distancia des del coll i uns $7 \mathrm{Km}$ des de la parada anterior.

Pels inicis d'aquest recorregut, hem anat tallant els nivells calcaris i dolomítics de Muschelkalk Inferior, ja vistos a la parada anterior. Més endavant, hem començat a tallar uns nivells de gresos i de lutites (i calcolutites) rogenques, amb nivells guixosos. Aquests nivells ja pertanyen al Muschelkalk Mig.

Precisament, cap als voltants del $\mathrm{Km} \mathrm{3}$, a l'indret de l'aturada es troba una antiga guixera, en la qual s'aprofitaven aquests nivells guixosos, per tal de ser utilitzats com a material de construcció. (fotografia 8). 


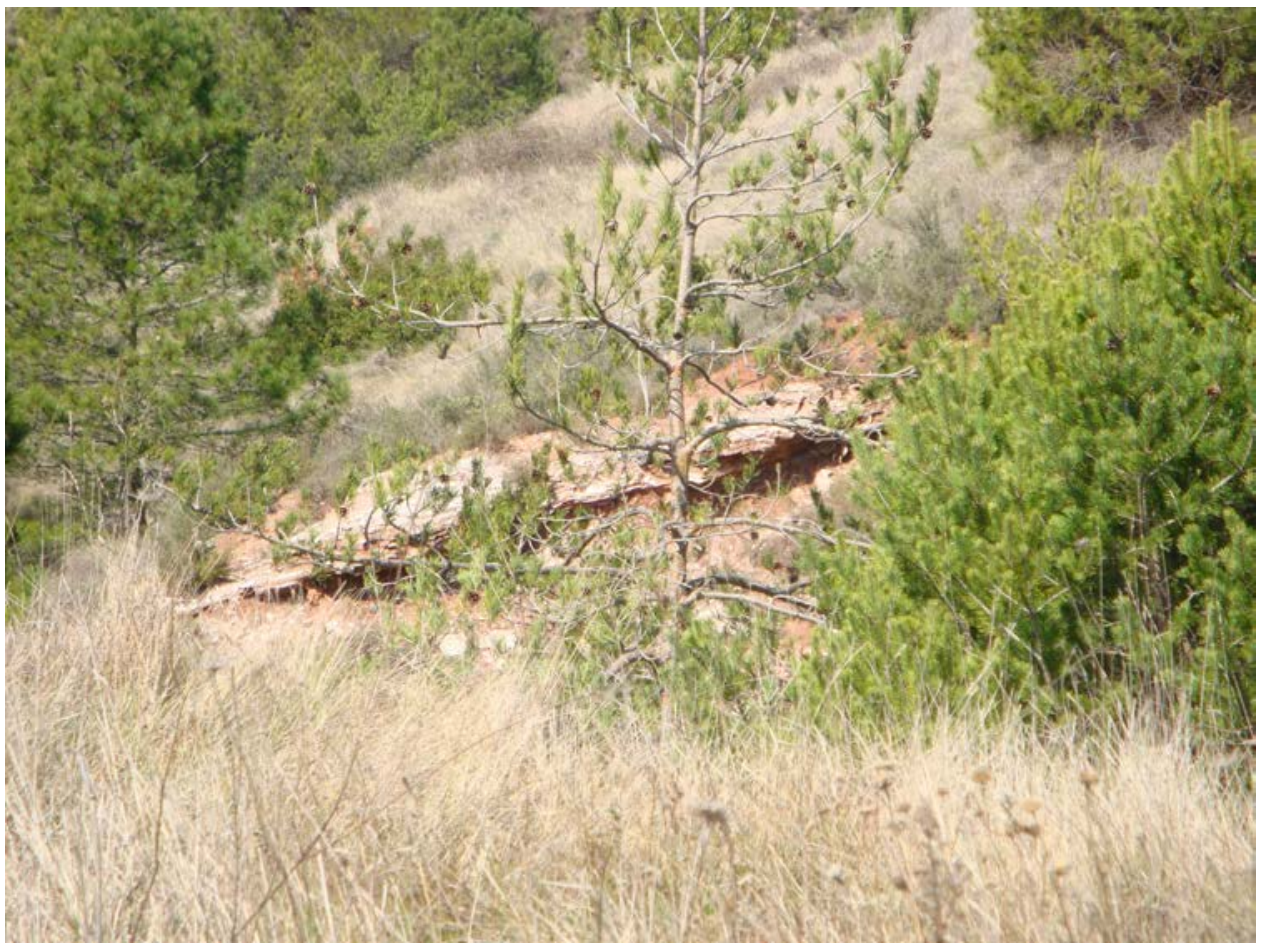

Fotografia 8. Aflorament dels guixos del Muschelkalk Mig

\subsection{Parada 8. CARRETERA LOCAL A "LOS CASTILLEJOS" I A LA FEBRÓ, IMMEDIACIONS DEL Km 7, (terme municipal de l'Arbolí, comarca del Baix Camp). (Full 445).}

Des de la parada anterior, cal continuar per la carretera TV-7092, la qual condueix cap a la Febró, i cap a l'antic Campamento Militar de los Castillejos. En arribar prop del Km 7 ens caldrà fer una nova aturada, a uns 4 de l'anterior.

Pels inicis d'aquest recorregut, hem anat tallant els nivells de gresos i de lutites (i calcolutites) rogenques, amb nivells guixosos, que pertanyen al Muschelkalk Mig. Més endavant, per sobre dels materials anteriors, es troben ja els dels Muschelkalk Superior, constituïts com els del tram inferior, per nivells carbonatats,. de calcàries i de dolomies.

Aquests materials, constitueixen els trams més alts de la cuesta, per on passa la carretera, i per sobre d'ells (com al Nord de los Castillejos), ja es troben els nivells lutítics i guixosos del Triàsic Superior, del Keuper.

Des de molts indrets d'aquest recorregut (i abans d'arribar a los Castillejos), es pot gaudir d'una impressionant visió de la Serralada Prelitoral Catalana, i també de la Depressió Prelitoral Catalana. Especialment dels materials mesozoics del Triàsic, per entre els quals discorre la carretera.

Així, es particularment interessant el tall que es pot gaudir cap els voltants del $\mathrm{Km}$. 7, de la carretera que anem seguint, tot anant cap a NE. (fotografía 9). 


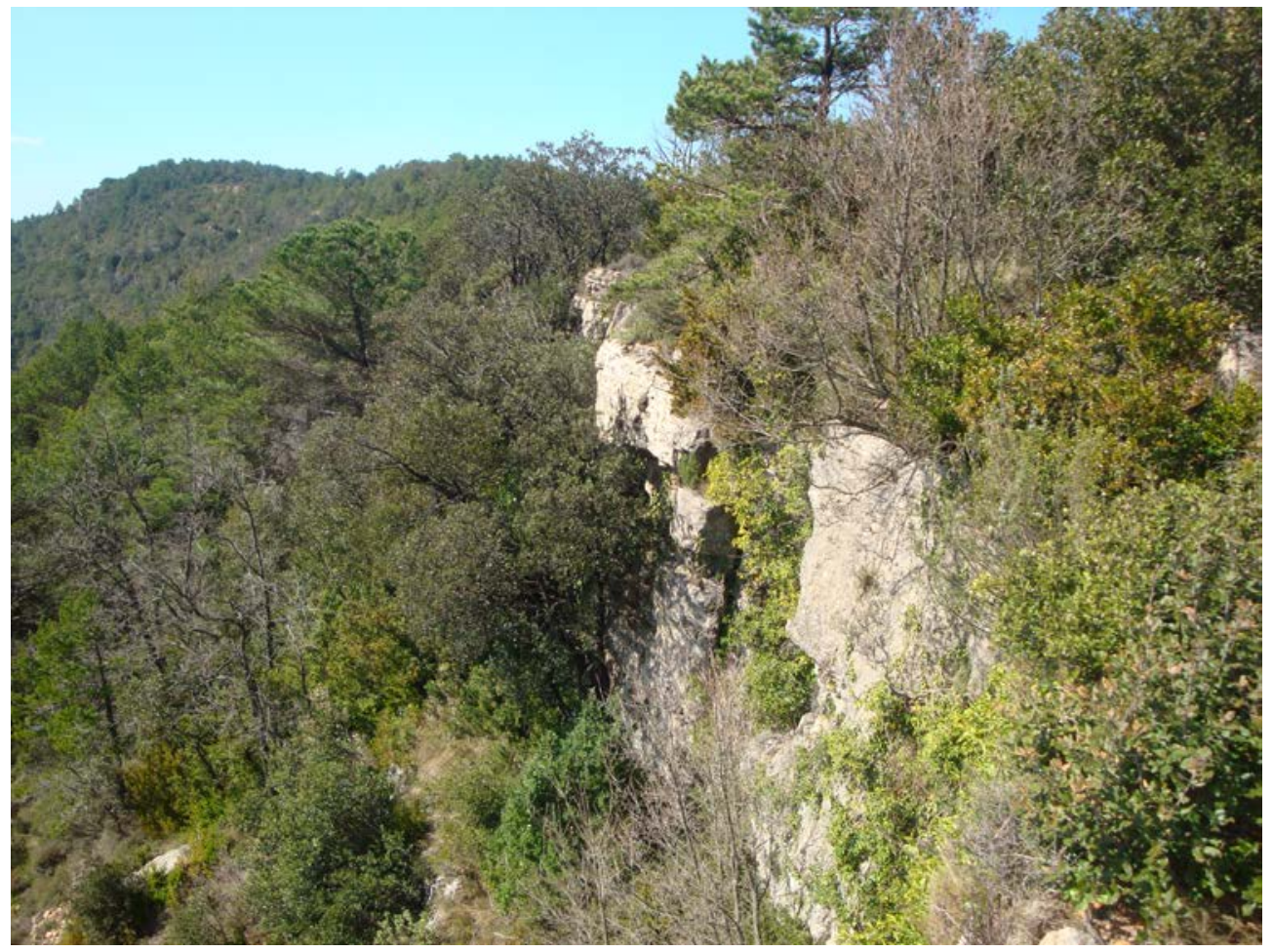

Fotografia 9. Aflorament dels nivells carbonatats del Muschelkalk Superior 


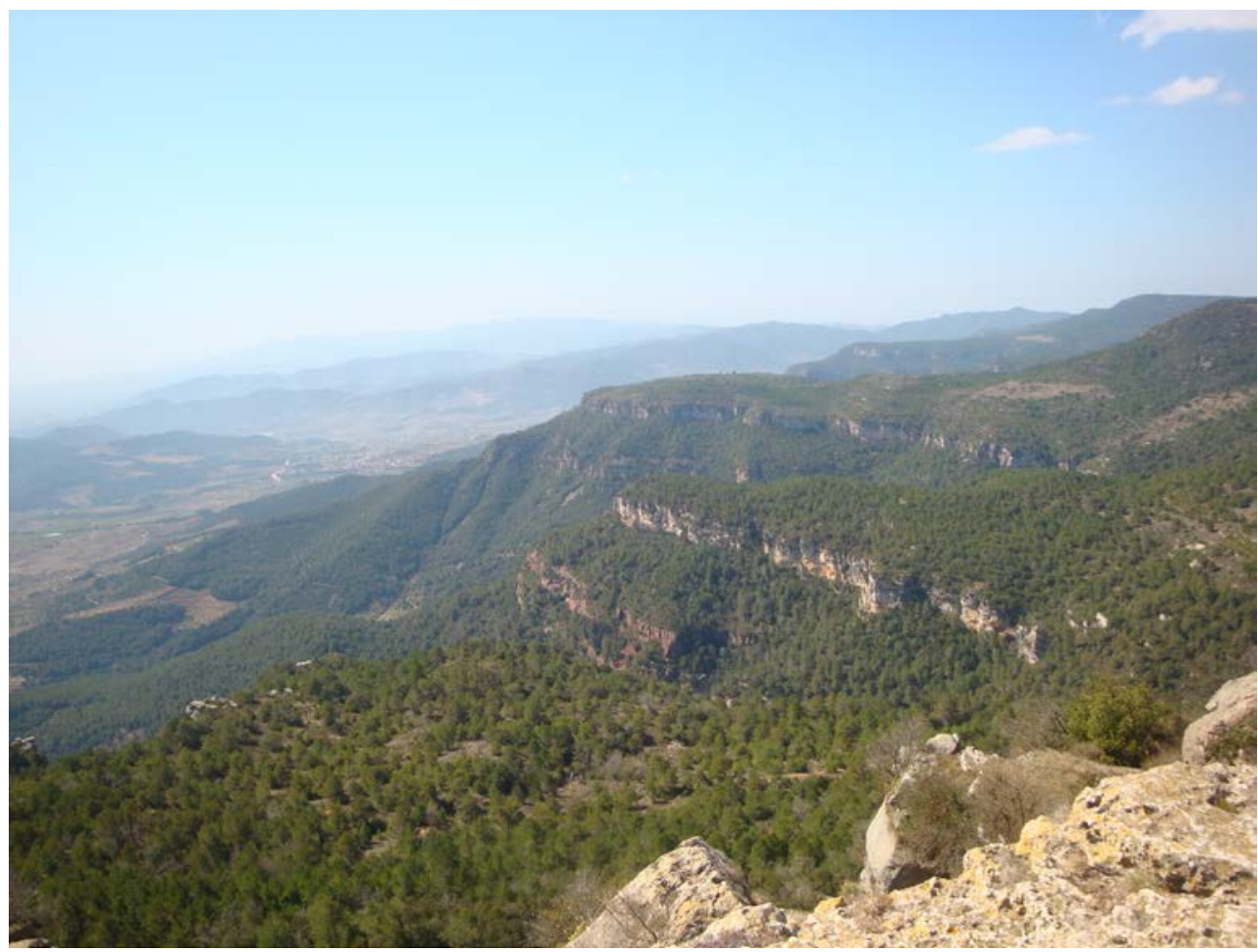

Fotografia 10. Aflorament dels nivells carbonatats del Muschelkalk Superior (en primer terme). Per sota es veu la zona on afloren els nivells rogencs del Muschelkalk Mig Per sota es veuen els nivells carbonatats del Muschelkalk Inferior. Tanmateix, per sota d'aquests es veuen els gresos del Buntsandstein I per sota els nivells del Carbonífer

\subsection{Parada 9. MIRADOR DE LA MUSSARA, (antic terme de la Mussara, actual de Vilaplana del Camp, comarca del Baix Camp). (Full 445).}

Poc després de passar per I'antic campament militar de los Castillejos, la carretera TV-7092 arriba a la cruïlla amb la carretera que es dirigeix cap a Prades, procedent de Reus, la T-704, per la qual continuar cap a llevant, tot fent una nova fillola, amb la intenció d'arribar a la cruïlla de la Mussara, i al poble, tot seguint la carretera TV-7093. En arribar-hi, i després de recórrer uns $6 \mathrm{Km}$, des de la parada anterior, cal fer la present, si s'escau.

En aquest trajecte, hem transitat pel contacte entre els nivells carbonatats del Muschelkalk Superior, amb els lutítics i guixosos del Keuper. I, ara ens trobem, precisament sobre aquest mateix contacte. De forma que la Mussara es troba sobre la cuesta que formen els materials carbonatats, i estenent-se més amunt els del Keuper.

Des d'aquest lloc, es pot gaudir d'un immillorable punt d'observació de la Serralada Prelitoral, (on estem situats), i també de la Depressió Prelitoral (Depressió del Camp), la qual s'estén amplament cap al Sud, d'on ara ens trobem situats. (fotografia 10).

En aquest indret finalitza el recorregut de l'itinerari

Xaragall.2015 n.4 | Recorregut de recerca geològica i mineralògica per les comarques del Baix Camp i del Priorat: des de les Borges del Camp a l'Alforja i a la Mussara 


\section{Bibliografia}

COLOMBO, F. (1986).- Estratigrafia y Sedimentologia del Paleógeno continental del borde meridional occidental de los Catalánides (provincia de Tarragona). Cuadernos de Geologia Ibérica, vol.10, pp.55-115. Madrid.

COLOMBO, F. (1989).- El Montsant; aspectes geològics (en "1O sortides per la Catalunya Sud"). 2on. Sympósium sobre l'Ensenyament de les Ciències Naturals, Tarragona. Edit. Eumo. pp.87-108. Barcelona.

GUIMERÀ, J. et altri /1992).- Geologia (II), Història Natural dels Països Catalans, Vol.2, 547 pag. Enciclopèdia Catalana, S,A,, Barcelona.

IGME (1978a).- Mapa Geològic de España a escala 1:50.000 (2a Sèrie). Full i memòria $n^{\circ} 445$ (Cornudella del Montsant). Inst. Tecnol. GeoMinero España. Madrid.

IGME (1978b).- Mapa Geològic de España a escala 1:50.000 (2a Sèrie). Full i memòria $n^{0} 472$ (Reus). Inst. Tecnol. GeoMinero España. Madrid.

MATA-PERELLÓ, J.M. (1991).- Els Minerals de Catalunya. Institut d’Estudis Catalans. Arxius de la Secció de Ciències, T.XLVIII, 506 pag. Barcelona.

MATA-PERELLÓ, J.M. (1995).- Apunts per a un itinerari geològico-mineralògic entre l'Alforja (Baix Camp) i Porrera (Priorat). Inèdit, 12 pàgines. Manresa.

MATA-PERELLÓ, J.M. (1996).- Itinerari geològic i mineralògic per les comarques del Priorat i del Baix Camp: des de Reus a Cornudella del Montsant, per Prades. Inèdit, 12 pàgines. Manresa.

MATA-PERELLÓ, J.M. (1998).- Recerca geològica i mineralògica per les comarques del Baix Camp i del Priorat: des de les Borges del Camp a Prades; i del Coll d'Albarca a Cornudella de Montsant, Xaragall, sèrie $B, n^{\circ}$ 100, 18 pag. Manresa.

MATA-PERELLÓ, J.M. (2000).- Recorregut de recerca geològica i mineralògica per les comarques del Baix Camp i del priorat: des de les Borges del Camp a Cornudella del Montsant i a la pobla de Cérvoles, Algeps, sèrie $B, n^{\circ} 127,16$ pag. Manresa.

MATA-PERELLÓ, J.M. (2004).- Recorregut de recerca geològica i mineralògica per les comarques del Baix Camp i del Priorat: des de Reus a I'Alforja, la Febró i Prades Inèdit, 10 pag. Manresa.

MATA-PERELLÓ, J.M. (2005).- Recorregut de recerca geològica i mineralògica per la comarca del Baix Camp: des de Pratdip a Mont-roig del Camp i des de les Borges del Camp a Prades. Inèdit. 12 pàgines. Manresa.

MATA-PERELLÓ, J.M. (2008a).- Recorregut de recerca geològica i mineralògica per les comarques del Baix Camp i del Priorat: des de Reus a l'Alforja, Cornudella, Ciurana i a Ulldemolins. Inèdit. 12 pàgines. Manresa.

MATA-PERELLÓ, J.M. (2008b).- Recorregut de recerca geològica i mineralògica per les comarques del Baix Camp i del Priorat: des de les Borges del Camp a I'Alforja i a la Venta del Pobill. Inèdit. 10 pàgines. Manresa.

MATA-PERELLÓ, J.M. (2011a).- Recorregut de recerca geològica i mineralògica per la comarca del Baix Camp: des de Reus al Coll d’Alforja. Inèdit. 10 pàgines. Manresa. 
MATA-PERELLÓ, J.M. (2011b).- Recorregut de recerca geològica i mineralògica per les comarques del Baix Camp i del Priorat: des de les Borges del Camp a I'Alforja i a Cornudella de Montsant. 10 pàgines. Manresa.

MATA-PERELLÓ, J.M. (2012).- Recorregut de recerca geològica i mineralògica per les comarques del Baix Camp i de la Conca de Barberà: des de Botarell i les Borges del camp a I'Alforja, la Febró, Prades i a Vilanova de Prades. Inèdit. 20 pàgines. Manresa.

MATA-PERELLÓ, J.M. i COLLDEFORNS, B. (1994).- Itinerari geològic i Mineralògic des d'Ulldemolins a les Borges del Camp. Inèdit, 12 pàgines. Manresa.

MELGAREJO,J.C. (1992).- Estudio geológico y metalogenético del paleozoico del sur de las Cordilleras Costeras Catalanas. Memórias dels Instituto Tecnológico y Geo-Minero de España, tomo 103, 605 pag. Madrid.

MELGAREJÓ, J.C. et altri (1993).- Mapa Metalogénico de España a escala 1:200.000. full i Memòria no 42 / 9-5 (Tarragona). Inst. Tecnol. GeoMinero España. Madrid.

RIBA, O. et altri (1976).- Geografia Física dels Països Catalans. Edit. Ketres, 254 pàgines. Barcelona. 